\title{
Haulm Forage Value of Lentil Varieties in Central Ethiopia
}

\author{
Asemahegn Mersha*, Debissa Lemessa \\ Ethiopian Biodiversity Institute
}

* Corresponding author email: asemahegnm@gmail.com

Received: 21 August 2019 / Revised: 29 October 2019 / Accepted: 13 November 2019 / Published: 14 November 2019

\begin{abstract}
The major livestock feed next to natural pasture in central highlands of Ethiopia is cereal crop residue; however, supplementation with additional nutritional entities is most often recommended. The present study aims to examine the nutritive value of lentil haulm and how this value varies among the varieties and locations. For this, $80 \mathrm{gms}$ of haulm samples of Alemaya, Derash and local lentil varieties were collected with four replications from Bishoftu, Akaki, and Chefe-Donsa from on farm trial sites of Ethiopian institute of agricultural research. To test for the variation in haulm nutritional values among the varieties, two-way ANOVA was employed. The results showed that the interaction of variety and location had significant effect on crude protein (CP), neutral detergent fiber (NDF), metabolizable energy (ME) and in vitro organic matter digestibility (IVOMD) $(\mathrm{P}<0.05)$. Here, CP content of lentil haulm was higher for a local variety when compared with the two commercial varieties. The haulm yield (4.38t/ha) and haulm dry matter yield (3.97 t DM/ha) were higher for Derash when compared with that of the local variety $(\mathrm{P}<0.05)$. Overall, the present finding denoted that although in some cases the lentil haulm nutritional values and yields vary among varieties and were dependent on growing locations, it can be observed to have optimum feeding values to supplement livestock feed with the cereal crop residues in central Ethiopia.
\end{abstract}

Keywords: Chemical composition, Crop-livestock production, Experimental location, Haulm nutritive value, lentil haulm, Lentil variety, Metabolizable energy, Nutritional analysis.

\section{Introduction}

In the highlands of Ethiopia, the integration of crop and livestock productions plays crucial role for livelihoods and biodiversity conservation [1]. Mixed crop-livestock production system provides stable return from limited land and capital, it also minimizes risk encountered during production, by diversifying sources of income and increase productivity. In this system livestock provide drought power to facilitate farming activities, offering quality food for the family, and supply organic fertilizer for crops [2]. However, in the mixed crop livestock production system of Ethiopia as demonstrated by, Wuletaw et al. [2] and [3] conversion of grazing land in to crop production is very often practiced in order to fulfill the food demand of the rapidly growing human population. According to study conducted by Hiwet et al. [4], in some parts of Ethiopia $41.88 \%$ of communal grazing land was changed in to crop land between the years of 1992 and 2012, because of an increase population size by $42 \%$. Similarly, in the central highlands of Ethiopia availability of quality feed resource from grazing lands has been gradually declined from year to year. On the other hand, the number of livestock increased along with the human population, it conversely resulted in feed shortage that manifested on low production and productivity of ruminant livestock [2].

Therefore, provision of crop residues as livestock feed is becoming more practical due to shortage of alternative feed resources during the dry season when both quantity and quality of available forage declines [4], [5]. The availability, quality, and yield of crop residues varies according to genotype, management factor and growing environment across different agroecology [3], [5]. Its abundance is started from the month of December to March, but gradually decline after April. According to study conducted 
by FAO [7], the crop residue produced was estimated to be about 32.9 million tones/year, of which $85.36 \%$ obtained from cereal crop residue in Ethiopia. Moreover, CSA survey indicated that crop residues contribute about $30.12 \%$ of the total feed utilized as shown in [8].

However, many studies showed that cereal straws and stovers are poor forage sources with lower crude protein, metabolizable energy, digestibility, and higher fiber fractions than legume haulms [9], [10]. Lentil is one of the most widely grown legume crop in the world. In most parts of the world where lentil crop cultivated the haulm is widely used as livestock feed. Moreover, many research findings confirmed that the haulm contains good quality feed for ruminant livestock [11],[12], which has lower NDF and ADF contents but higher rumen degradability, digestibility, palatable, protein, calcium and phosphorus than cereal crop residues [4], [5],[13],[14]. According to study conducted in different parts of the world the yield and nutritional quality of lentil haulm differs according to variety, environmental condition and agronomic practice of lentil crop [9], [14], [1], [2]. Even though, different varieties of lentil crop widely grown in central Ethiopia, most of the study were exhaustively focused on other food crops, "as indicated by Abraham, instead little attention was given to research, development and external fund attraction for lentil [15]". In the same manner, considering haulm chemical composition and nutritional values as livestock feed low research activities were undertaken so far.

Therefore, it is paramount important to know and exploit the empirical facts on the potential forage values of the haulm of different lentil varieties, so as to provide update information for future development activities and research work. Hence, the aims of the study were to evaluate and compare the forage value of the haulm of three lentil varieties grown at three different locations in central Ethiopia and assess the effects of location and variety on haulm nutritional value of the lentil. Here, it was hypothesized that the haulm forage values of lentil vary among the varieties and this variation was also mediated by the growing locations.

\section{Research Methodology}

\subsection{Sample collection sites}

The haulm samples were collected from the research centers of Ethiopian Agricultural Research institute namely: Bishoftu, Akaki and Chefe Donsa. Here, Bishoftu is located at $45 \mathrm{~km}$ southeast of Addis Ababa, Akaki, site is situated at $30 \mathrm{~km}$ northwest of Bishoftu site while Chefe Donsa is located at $35 \mathrm{~km}$ east of Bishoftu research site (Figure 1).

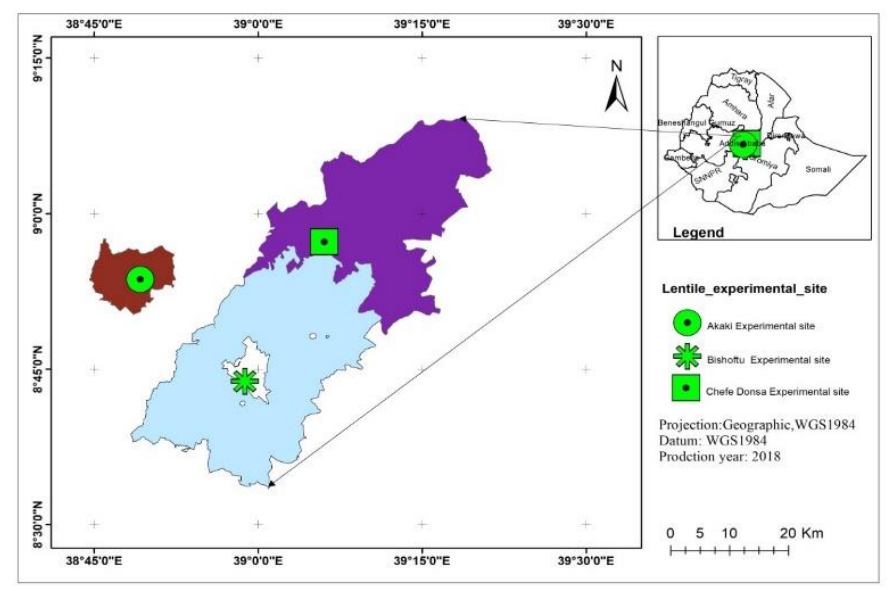

Figure 1: The map showing the locations of three sites from where the haulm samples of lentil collected.

\subsection{Sample Collection and Nutritional Analysis}

All the samples were ground and sieved in $1 \mathrm{~mm}$ sieve size before scanning and about two spoonfull of the sample were put in paper bags and predried at $60^{\circ} \mathrm{C}$ overnight in an oven to standardize moisture conditions. Partially dried samples were put into NIRS cup and NIRS machine of Foss 5000 in the $1108-2492 \mathrm{~nm}$ spectral ranges was used to scan samples of lentil haulm. For the purpose of wet chemistry analysis 15 representative samples were selected from all scanned samples using NIRS software of Win Scan version 1.5, 2000, intrasoft international, L.L.C. The samples were analyzed for DM, OM and total ash contents by the procedures of [16] and Nitrogen was determined by Kjeldahl method [16] and CP was calculated as $\mathrm{N} \times$ x 6.25. The NDF, ADF and ADL contents were analyzed following the recommendations of Peter and James [17] in ILRI laboratory. In vitro gas production [17] test was carried out at ILRI Animal Nutrition laboratory in India. The ME 
Mersha et al., Int. Ann. Sci.; Vol. 9, Issue 1, pp: 8-15, 2020

and true in vitro organic matter digestibility were estimated based on gas production parameter.

The estimated $\mathrm{ME}$ value $(\mathrm{MJ} / \mathrm{kg} \mathrm{DM})$ was calculated following the equations of Menke and Steingass [18] as:

$$
\begin{gathered}
\mathrm{DO}=15.38+(0.8453 * \mathrm{GP}+(0.595 * \mathrm{CP} \%)+ \\
(0.181 * \text { ash }), \mathrm{ME}(\mathrm{MJ} / \mathrm{kg} \mathrm{DM})=2.2+ \\
\left(0.136^{*} \mathrm{GP}\right)+(0.0057 * \mathrm{CP} \mathrm{g} / \mathrm{kg}),
\end{gathered}
$$

$\mathrm{GP}=((\mathrm{V} 24-\mathrm{V} 0-\mathrm{GP} 0) *$ altitude correction factor $\left.* 0.2) / \mathrm{Sw}^{*} \mathrm{DM} * 0.01\right)$,

Where,

$\mathrm{GP}=$ Blank without feed sample, but with fluid, $\mathrm{CP}=$ Crude protein,

$\mathrm{DO}=$ Digestible organic matter, V24= Gas volume at 24 hours ( $\mathrm{ml} / 200 \mathrm{mg})$,

$\mathrm{V} 0=$ volume at 0 hour,

Sw $=$ sample weight.

\subsection{Statistical Analysis}

The variation in forage nutritional values of lentil haulms among the varieties and how the variations are affected by locations were tested using two-way ANOVA, where, varieties and locations were entered as both main factors and interaction factors). For the results we found the variation in nutrition values among varieties and locations, the mean separation or multiple comparison of the means was computed using Tukey HSD tests. These analyses were run using the R statistical program (Version 3.5.1) [19].

\section{Results and Discussion}

The two-way ANOVA showed that the nutritional values of lentil haulm including crude protein (CP), neutral detergent fiber (NDF), metabolizable energy (ME) and in vitro organic matter digestibility were significantly affected by the interaction effect of variety by location $(\mathrm{P} \leq 0.05)$ (Table 1). This implies that these haulm chemical composition and nutritional values of lentil genotypes were unstable or inconsistency across the experimental location. This is the results of the joint effects of genotype and environment. Moreover, Habte et al. demonstrated that interaction of genotype by environment indicated the difference in the response of genotypes to the different environmental conditions [20]. According Kebede et al. [21] suggestion when such interaction is encountered conducting stability analysis for identification of superior genotypes with wide adaptation or sensitive for different environments has to be performed.

The experimental location had significant effects on $\mathrm{CP}, \mathrm{NDF}, \mathrm{ADF}$, Ash, ME, organic matter digestibility $(\mathrm{P}<0.01)$ and also on haulm yield at $(\mathrm{P}<0.05)$. This significant effects of location on the whole study parameters has indicated that the tested traits were varied from one experimental site to other experimental sites or differ from environment to environment. Similarly, Berhanu et al. [22] study showed that effect of environment on quality and quantity of crop residues of maize tend to be larger than genotypic effect. Which may be due to the response of crops to spatial environmental variations like soil and climatic conditions.

Moreover, in the present study variety had significant effect on haulm CP $(\mathrm{P}<0.001)$, NDF and haulm yield at $(\mathrm{P}<0.05)$ significant levels (Table 1). Indicates the presence of genetic variation in these fodder traits.

\begin{tabular}{|c|c|c|c|c|c|c|c|c|}
\hline \multirow{2}{*}{ S.O. V } & \multirow{2}{*}{ DF } & \multicolumn{7}{|c|}{ Mean Squares } \\
\hline & & $\mathrm{CP}$ & NDF & $\mathrm{ADF}$ & Ash & $\mathrm{ME}$ & IVOMD & HLY \\
\hline Variety & 2 & $6.13^{* * *}$ & $22.2^{*}$ & $13.14 \mathrm{~ns}$ & $0.34 \mathrm{~ns}$ & $0.05 \mathrm{~ns}$ & $0.25 \mathrm{~ns}$ & $3.17^{*}$ \\
\hline Location & 2 & $33.91^{* * *}$ & $177.91^{* * *}$ & $131^{* *}$ & $21.16^{* * *}$ & $0.47^{* * *}$ & $18^{* *}$ & $1.19^{*}$ \\
\hline $\mathrm{V} \& \mathrm{~L}$ & 4 & $2.17^{* *}$ & $16.92^{*}$ & $12.7 \mathrm{~ns}$ & $0.28^{\mathrm{ns}}$ & $0.17^{*}$ & $11.66^{*}$ & $1.08^{\mathrm{ns}}$ \\
\hline Error & 26 & 1.24 & 7.07 & 6.54 & 0.32 & 0.08 & 3.63 & 0.66 \\
\hline
\end{tabular}

Table 1: Combined analysis of variance mean squares due to variety, location and the interaction between variety and location on study parameters. 
Haulm Forage Value of Lentil Varieties in Central Ethiopia

Table 2: Mean comparisons of haulm chemical composition, feed quality and yield among lentil varieties

\begin{tabular}{|l|l|l|l|l|l|l|l|l|}
\hline variety & $\begin{array}{l}\mathrm{CP} \\
\text { \%DM }\end{array}$ & $\begin{array}{l}\text { Ash } \\
\% \mathrm{DM}\end{array}$ & $\begin{array}{l}\text { NDF } \\
\% \mathrm{DM}\end{array}$ & $\begin{array}{l}\text { ADF } \\
\% \mathrm{DM}\end{array}$ & $\begin{array}{l}\text { ME } \\
\text { MJ/kg DM }\end{array}$ & $\begin{array}{l}\text { IVOMD } \\
\% \mathrm{DM}\end{array}$ & $\begin{array}{l}\text { HLY } \\
\text { t/ha }\end{array}$ & $\begin{array}{l}\text { HDMY } \\
\text { t DM/ha }\end{array}$ \\
\hline Local & $8.11^{\mathrm{a}}$ & $9.80^{\mathrm{a}}$ & $51.96^{\mathrm{a}}$ & $37.99^{\mathrm{a}}$ & $8.10^{\mathrm{a}}$ & $55.25^{\mathrm{a}}$ & $3.41^{\mathrm{b}}$ & $3.09^{\mathrm{b}}$ \\
\hline Derash & $6.99^{\mathrm{b}}$ & $9.66^{\mathrm{a}}$ & $50.17^{\mathrm{ab}}$ & $36.80^{\mathrm{a}}$ & $8.06^{\mathrm{a}}$ & $54.86^{\mathrm{a}}$ & $4.38^{\mathrm{a}}$ & $3.97^{\mathrm{a}}$ \\
\hline Alemaya & $6.93^{\mathrm{b}}$ & $9.48^{\mathrm{a}}$ & $49.50^{\mathrm{b}}$ & $36.80^{\mathrm{a}}$ & $8.14^{\mathrm{a}}$ & $55.02^{\mathrm{a}}$ & $3.94^{\mathrm{ab}}$ & $3.57^{\mathrm{ab}}$ \\
\hline Mean SE \pm & $\mathbf{7 . 2 0}$ & $\mathbf{9 . 7 4}$ & $\mathbf{5 0 . 5 1}$ & $\mathbf{3 6 . 7 7}$ & $\mathbf{8 . 0 9}$ & $\mathbf{5 4 . 9 8}$ & $\mathbf{3 . 8 9}$ & $\mathbf{3 . 5 2}$ \\
& $\mathbf{0 . 1 1}$ & $\mathbf{0 . 0 8}$ & $\mathbf{0 . 3 9}$ & $\mathbf{0 . 3 7}$ & $\mathbf{0 . 0 4}$ & $\mathbf{0 . 2 8}$ & $\mathbf{1 . 3 6}$ & $\mathbf{0 . 1 2}$ \\
\hline
\end{tabular}

DM; dry matter, MJ/kg DM; Mega joule per kilo gram dry matter, OM; organic matter, HDMY; Haulm dry matter yield, t/ha; tone per hectare, t DM/ha; tone dry matter per hectare, SE=standard error of the mean; means within column do not share a letter are significantly different at $\mathrm{P}<0.05$ level.

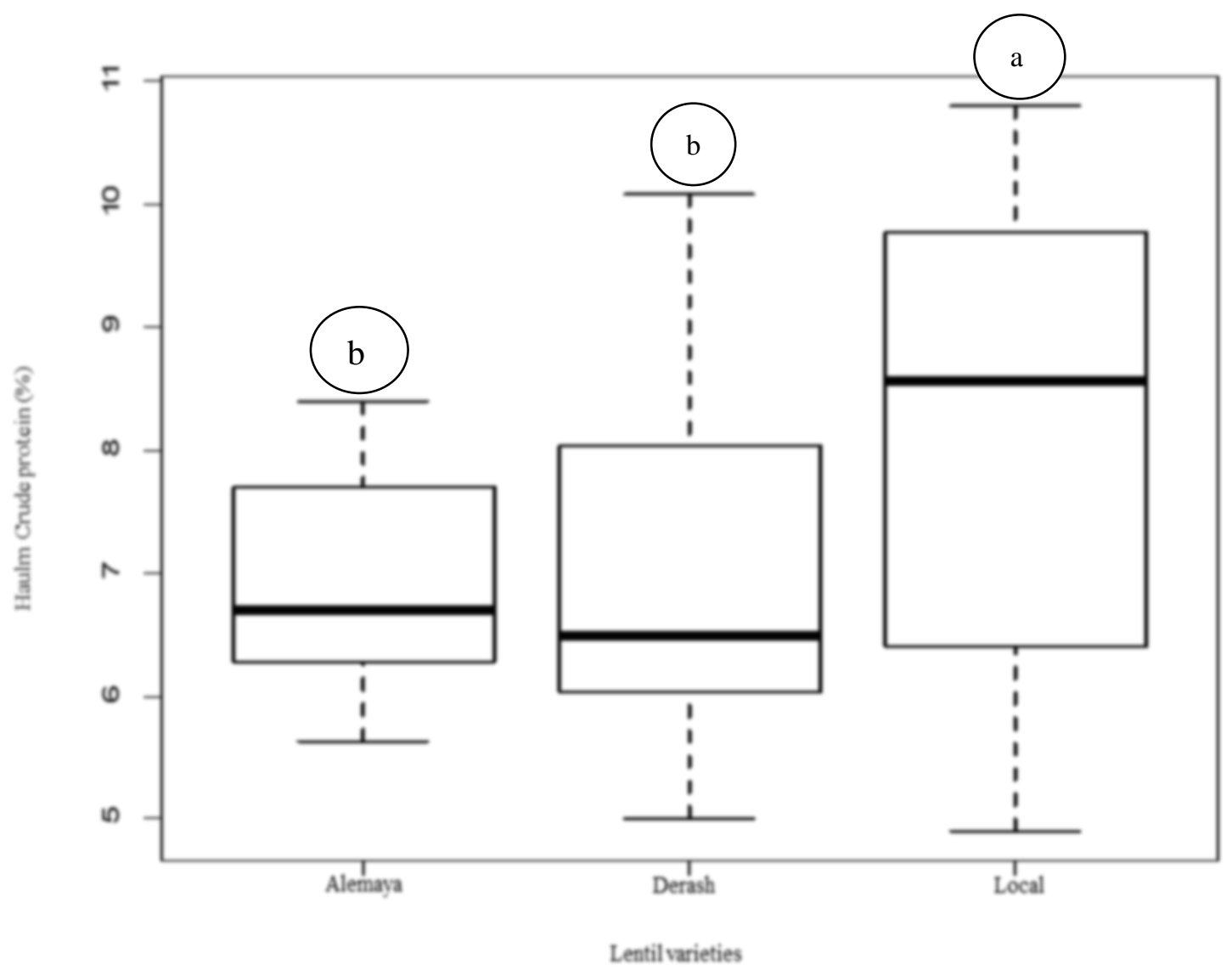

Figure 2: The boxplot showing the variation in haulm crude protein values among the lentil varieties. The Tukey HSD test multiple comparison of the means showing that the different lower-case letters in the figure indicate the significant differences $(P=0.01)$.

The result of multiple comparisons for the means showed that CP was higher for local variety compared with the two improved varieties (Table 2 and Fig.2), in contrast to Yafeng, Fangfang and Zhibiao result who obtained lower CP value from haulm of local vetch variety than improved [23] on the other side they indicated that variety had a significant influence on the protein fractions of the haulm. That might be due to better inherent characteristics of the Local variety to fix nitrogen from the atmosphere as a result of long-lasting environmental adaptation. Moreover, $75 \%$ of the value of Crude protein had relatively wider range for Local variety (6.16-10.8\%) and Derash (6.03$10.08 \%)$ than variety Alemaya which had range of $6.28-8.39 \%$ (Figure 2). That might be because of variation within the species and also proportion of plant parts during chemical analysis like stem to leaf ratio as explained by Ramazan et al. during analysis of wheat straw and lentil haulm [23].

The overall mean of haulm crude protein of each variety is relatively within the range of result (5.8- 
Mersha et al., Int. Ann. Sci.; Vol. 9, Issue 1, pp: 8-15, 2020

8.6\%) reported by Heuze et al. [24], also within the optimum rumen microbial requirement for fermentation and effective degradation 6.25$7.5 \%$ according to Peter [25]. Similarly, the overall mean is match the values reported by Dereje, Seyoum and Zinash [26] for CP content of lentil straw in Ethiopia; however, higher than the values that were reported by several previous findings such as Narayan, Sharma and Uma [27], S.Nigam and Michael [28], while lower than the lentil CP value as showed by Eyob et al. [9] and [28] this might be due to difference in variety, environmental and managemental conditions among the different studies.

According to Peter, when considering crop residues as livestock feed the major limiting factor is crude protein content, which is more attributed in cereal straws than legume haulms [25]. Therefore, in the present study the CP values were within the critical level for maintenance requirement of ruminants. It can thus be used as a supply with poor quality forage in crop-livestock production systems.

The NDF value was higher $(\mathrm{P}<0.05)$ for Local variety $(52 \%)$ than Alemaya variety $(49.5 \%)$; but, no difference $(\mathrm{P}>0.05)$ observed among Derash, with Local and Alemaya varieties. The overall mean values of NDF and ADF in the present study are lower than Cowpea and groundnut haulms reported by Anandan et al. [30] which were $64 \%$ and $39.6 \%$ respectively. However, the mean value of NDF obtained was match with the result of Eyob et al. finding (52\%) of lentil haulm, but the acid detergent fiber (ADF) contents was higher [9].

Considering the comparative feeding value of the haulm, we observed that the values of the two fiber fraction (NDF and ADF) were within the medium ranges of forage quality (45-65\% and 31 $45 \%$, respectively) this favors optimum feed intake and stimulating rumen function and cud chewing for ruminant livestock as indicated by Singh and Oosting [31]. No different $(\mathrm{P}>0.05)$ was observed in Ash, ADF, metabolizable energy and in vitro organic matter digestibility (IVOMD) among the varieties.

The haulm yield (4.38t/ha) and haulm dry matter yield $(3.97 \mathrm{t} \mathrm{DM} / \mathrm{ha})$ were higher for Derash variety $(\mathrm{P}<0.05)$ than Local variety (Table 2, Figure 3). Recent studies in Ethiopia indicated that Derash had larger plant height and biomass yield compared with other varieties, as these agronomic traits are highly and positively associated with haulm yield [32] and [33] the haulm yield and haulm dry matter yield of Derash showed higher values than Local in the present study. On the other hand, $50 \%$ of the value of haulm yield was concentrated from 3.53$5.09 \%$ range in Derash, $2.91-4.92 \%$ in Alemaya and in Local variety $3.03-3.78 \%$ (figure 3 ). The varieties Derash and Alemaya had haulm yield advantages of $28.45 \%$ and $15.54 \%$ respectively over Local variety.

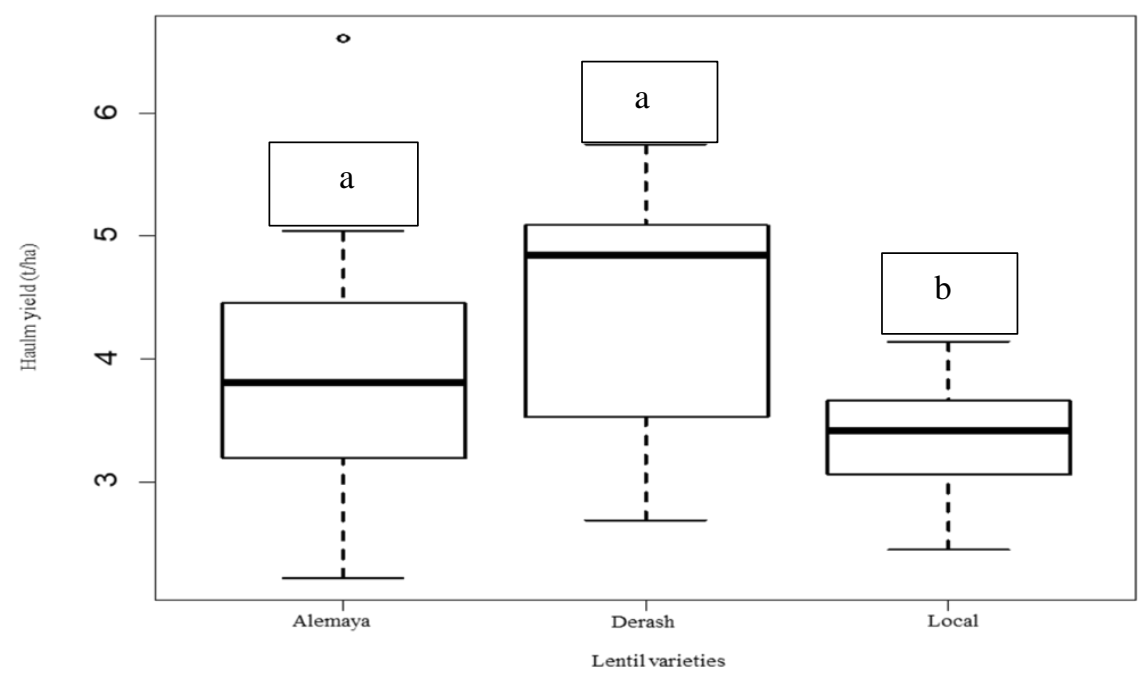

Figure 3: The boxplot showing the variation in haulm yield among the lentil varieties. The Tukey HSD test multiple comparison of the means showing that the different lower-case letters in the figure indicate the significant differences $(P=0.01)$. 
The values of metabolizable energy in the present study in each genotype were greater than the results of most of the tropical legume forages species studied by Evitayani et al. [34] and the result obtained by Teklu et al. on faba bean haulm [35]. In similar manner, the results were higher than different cereal and legume straws assessed by Secundino et al. with the exception of leaf rich samples of Lens culinaris and Phaseolus vulgaris [36]. However, these results were lower than the values of legume hay studied by Omer $e t$ al. which had ME results of minimum $8.98 \mathrm{MJ} / \mathrm{kg} \mathrm{DM}$ and maximum $10.30 \mathrm{MJ} / \mathrm{kg} \mathrm{DM}$ values [36]. That could be due to genetic, environmental and managemental factors. On the other hand, the results were similar to Eyob et al. lentil haulm value [9].

The true in vitro organic matter digestibility of all tested varieties were lower than the results obtained by Omer et al. [37], however, they are above $50 \%$ indicating the possibility to supply relatively high metabolizable energy, as demonstrated by A.K. Mosi and M.H. Butterworth [38] crop residues with less than $50 \%$ OM digestibility reduce feed intake ultimately offers low energy values for ruminant livestock. Therefore, as organic matter digestibility and ME are very important parameters to evaluate and compare forages, in the present study the result obtained were able to meet the ruminant livestock forage maintenance requirement threshold.

According to Evitayani et al. [34] digestibility of legumes haulm depends on chemical composition particularly, fiber fractions and silica contents, forage species, leafiness, and soil fertility and other environmental factors. B. D. Thomson et al. indicated that because of the indeterminate growth habit of lentil crop it continues to flower and sprout new braches which varies across varieties that may increase biomass, yield and haulm digestibility [39].

In general, most of the tested feeding values of lentil haulm had significantly affected by growing environment, while a few of them were affected by genotype. The haulm of the lentil varieties had optimum nutritive quality compared with other crop residues. However, Local variety was identified to have better CP, while Derash had high haulm yield and haulm dry matter yield. Therefore, the result of the present study indicated that the nutritional values of studied lentil haulm are better than other most crop residues in the mixed crop livestock production system of Ethiopia and could support in supplementation of poor forage quality.

\section{Conclusion}

Like grain and other agronomic traits of lentil in Ethiopia, the haulm yield and haulm nutritional values of the lentil varieties tested are promising to be used as supplementation of poor forage quality. However, these values were mediated by the varieties and locations or by the spatial variations in environmental factors. In general, it is suggested that further studies should be conducted in terms of animal performance, the study should be also carried out for more oneyear experimental time, Local varieties has not been overlooked. When considering crop improvement program and strategies, both grain and haulm traits of lentil should be focused.

\section{Declarations}

\subsection{Acknowledgements}

The authors would like to acknowledge International Center for Agricultural Research in Dry Areas (ICARDA) for the financial support and the Ethiopian Institute of Agricultural Research, DebreZeit Station for facilitating field activities and, also to the Animal Nutrition Laboratory of the international livestock research Institute (ILRI), Addis Ababa and Patancheru, India for analyses of haulm samples.

\subsection{Competing Interests}

The authors declared that no conflict of interest exist in this publication.

\section{How to Cite this Article}

A. Hailegiorgis and D. Lemessa, "Haulm Forage Value of Lentil Varieties in Central Ethiopia", Int. Ann. Sci., vol. 9, no. 1, pp. 8-15, Nov. 2019. doi: 10.21467/ias.9.1.8-15 
Mersha et al., Int. Ann. Sci.; Vol. 9, Issue 1, pp: 8-15, 2020

\section{References}

[1] Wuletaw. M and Kindu. M," Determinants of croplivestock diversification in the mixed farming systems: evidence from central highlands of Ethiopia", Agric. Food Secur., vol. 7 issue 60, Aug. 2018.

[2] Wuletaw. M, Kindu. M, Peter. T, Melkamu. B , Lulseged. $\mathrm{T}$ and Wuletawu. A, "Competition for land resources: driving forces and consequences in croplivestock production systems of the Ethiopian highlands", Ecol. Process, vol.7, issue 30, pp.2-15, Sep. 2018.

[3] Hiwet. G, Girmay. G, Nigussie. A, Mengsteab. H, Kassa. $\mathrm{T}$ and Shimbahri. M,"Conversion of communal grazing land into arable land and its impacts on soil properties and vegetation cover" Arid Land Res. Manag., vol.3, issue 2, pp.236-252. Dec. 2017.

[4] Solomon B, Solomon. M and Alemu. Y, "Potential use of crop residues as livestock feed under smallholder farmer's conditions in Bale highlands of Ethiopia", Trop. Subtrop. Agro-ecosyst., vol.8, no.1, pp. 107-114.Jan. 2008.

[5] B.V.S. Reddy, P.Sanjana, Reddy, F. Bidinger, Michel. B, (2003, Mar). "Crop management factors influencing yield and quality of crop residues", Field Crops Res., vol. 84, pp. 57-77, Mar. 2003.

[6] Getahun.B and Tegene. N, "Livestock Feed Dry Matter availability and utilization in Burie Zuria District, North Western Ethiopia", Trop. Subtrop. Agroecosyst., vol.22, pp.55-70, Fab, 2019.

[7] (FAO) Food and Agriculture Organization of the United Nations. "Ethiopia Report on feed inventory and feed balance", 2018, Rome. ISBN 978-92-5-131004-5.

[8] (CSA) Central Statistical Agency of Ethiopia. "Agricultural sample survey report for 2009/2010 EC". Addis Ababa, Ethiopia. Apr.2018.

[9] Eyob. H, Mathew. G, Francis. K. N, Goitom. A, "Determining nutritive value of cereal crop residues and Lentil (Lens esculanta) straw for ruminants", J. Anim. Sci., vol.7, pp.19-29, Jan. 2017.

[10] Mekuanint. G and Girma. D, "Livestock feed resources, nutritional value and their implication on animal productivity in mixed farming system in Gasera and Ginnir Districts, Bale Zone, Ethiopia," Int. J. Livest. Prod., vol. 8, issue 2, pp. 12-23, Feb. 2017.

[11] Narayan. D, K. Sharma, Uma. N, "Nutritional evaluation of lentil (Lens culinaris) straw and urea treated wheat straw in goats and lactating buffaloes", Asian-Australas J. Anim. Scivol.,17, no. 11, pp.1529-1534, Jan. 2004.

[12] S.G. Haddad and Husein, M. Q. Nutritive value of lentil and vetch straws as compared with alfalfa hay and wheat straw for replacement ewe lambs. Small Ruminant Res., vol.40, issue 3, pp.55-260, Jun. 2001.

[13] Sultan. S, B. P. Kushwaha, S. K. Nag, A. K. Mishra, S. Bhattacharya , P. K. Gupta and A. Singh, 'In vitro methane emission from Indian dry roughages in relation to chemical composition" cur.sci., vol.101, no.1, July, 2011.

[14] Ramazen. D, Polat. I, Ali.M. T and Dilek. S. D, "The effects of dietary wheat straw, Red lentil straw and equal mixtures of straw as ad libutum on intensive fattening performance, some serum minerals and economic efficiency in Awassi Lambs", J. Anim. Vet. Adv., vol.11, no.11, pp.1890-1896, 2012.

[15] Abraham. R, "Lentil (Lens Culinaris Medikus) Current status and future prospect of production in Ethiopia",
Advances in Plants \& Agriculture Research, Vol. 2 Issue 2, Mar.5, 2015.

[16] Official method of analysis, 15th ed. Association of Official Analytical Chemists (AOAC). Arlington, VA, USA, 1990.

[17] Peter. V. J and James. R. B, "Analysis of forages and fibrous foods", a laboratory Manual 613. Cornell University, N.Y., USA, 1985.

[18] K. Menke.H and H. Steingass, 1988. "Estimation of the energetic feed value obtained from chemical analysis and in vitro gas production using rumen fluid", In: Anim. Res. Dev., vol.28, pp. 7-55, 1985.

[19] $\mathrm{R}$ Core Team. R Foundation for Statistical Computing.Vien, Austria., R: A language and environment for statistical computing. 2018.

[20] Habte. J, Kebebew. A, Kassahun.T, Kifle. D and Zerihun. T, "Genotype-by-Environment interaction and stability analysis in grain yield of improved Tef (Eragrostis tef) varieties evaluated in Ethiopia”, J. Exp. Agri. Inter., vol.35, issue 5, pp.1-13, May 2019.

[21] Kebede. D, Dagnachew. L, Girma. M, Kassa. M, Chemeda. B, Girma C and Gudeta. B, "Genotype by Environment interaction and grain yield stability analysis for Finger Millet (Eleusine coracana (L.) Gaertn) genotypes from Western Oromia Ethiopia" J. Crop Sci., vol. 6 No.1, 2018.

[22] Berhanu.T. E, S. Twumasi-Afriyie, Michael. B, Dennis. F, Demewoze. N, Mosisa. W, Demissew. A and Kheri. $\mathrm{K}$, "Genetic variability of maize stover quality and potential for genetic improvement of fodder value", Field Crop Res., no, 152, pp.79-85, Sep. 2013.

[23] Yafeng.H, Fangfang.Z and Zhibao.N, "omparative Grain Yield, Straw Yield, Chemical Composition, Carbohydrate and Protein Fractions, In Vitro Digestibility and Rumen Degradability of Four Common Vetch Varieties Grown on the Qinghai-Tibetan Plateau", Animal (Basel),vol.9, issue 8, p.505, Jul. 31, 2019.

[24 Ramazen. D, Polat. I, Ali.M. T and Dilek. S. D, "The effects of dietary wheat straw, Red lentil straw and equal mixtures of straw as ad libutum on intensive fattening performance, some serum minerals and economic efficiency in Awassi Lambs", J. Ani. Vet. Adv., vol.11, no.11, pp.1890-1896, 2012.

[25] Heuze. V, Tran. G, Sauvant. D, Bastianelli. D, Lebas. F, Lentil (Lens culinaris). Feedipedia, a programme by INRA, CIRAD, AFZ and FAO. May 11, 2015.

[26] Peter. V. J, Nutritional Ecology of the Ruminant, 2nd ed. New York, Cornell University Press, Ithaca, USA, 1994.

[27] Dereje. F, Seyoum. B and Zinash. S," Characterizing and predicting chemical composition and in vitro digestibility of crop residue using near infrared reflectance spectroscopy (NIRS)", Livestock Res. Rural Dev., vol. 22, no.2, Jan. 2010.

[28] Narayan. D, K. Sharma, Uma. N, "Nutritional evaluation of lentil (Lens culinaris) straw and urea treated wheat straw in goats and lactating buffaloes", Asian-Australas J. Anim. Sci., vol.17, no. 11, pp.1529-1534, Jan. 2004.

[29] S. Nigam. N and Michael. B," Cultivar-Dependent Variation in Food-Feed Traits in Groundnut (Arachis hypogaea L.)", Anim. Nutr. Feed Techn., vol.10 (special issue), pp. 39-48, 2010.

[30] Vishal. M, Mukesh. K.M, Ashok. S.R, "Lentil straw (Lens culinaris): An alternative and nutritious feed resource for kids", Anim. Nutr., vol.4, Issue 4, pp.417421. 
[31] Anandan. S, Ousmane. B, Elaine. G, Christian. A. F, Prasad. K, Ravi. D, Iheanacho. O and Michael. B,"Cowpea and Groundnut Haulms Fodder Trading and Its Lessons for Multidimensional Cowpea Improvement for Mixed Crop Livestock Systems in West Africa", front plant scienc., Aug.10, 2016 Accessed on Jan. 31, 2017.

[32] Singh. G. P and S.J. Oosting," A model for describing the energy value of straws', Indian Dairyman., vol.15, pp. 322-327,1992.

[33] Daniel. A. B, Firew. M, Asnake. F,"Genetic Improvement of Lentil [Lens culinaris Medikus] Between 1980 and 2010 in Ethiopia", Malays. j. med. biol., Vol. 2, No. 3, 2015.

[34] Yirga. K and Zinabu.N, "Participatory evaluation of lentil varieties in Wag-lasta, Eastern Cogent Food \& Agriculture., vol.3, pp1-12, Dec. 2018.

[35] Evitayani1, L. Warly, A. Fariani, T. Ichinohe and T. Fujihara, "Study on nutritive value of Tropical forages in North Sumatra", Asian-Aust. J. Anim. Sci., vol. 17, issue 11, pp. 1518-1523, 2004.

[36] Teklu. W, Adugna. T, Jane. W, Getachew. A and Barbara. R, "Effects of feeding different varieties of faba bean (Vicia faba L.) straws with concentrate supplement on feed intake, digestibility, body weight gain and carcass characteristics of Arsi-Bale sheep", AsianAustralas J Anim Sci., vol. 31, no. 8, pp.1221-1229, Aug. 2018.

[37] Omer. S. U, Ozer. K, Emrah. Adem.K, "Effect of species on chemical composition, metabolizable energy, organic matter digestibility and methane production of some legume plants grown in Turkey", J. Appl. Anim. Res., vol.46, issue 1, pp.1158-1161, May 31, 2018.

[38] Secundino. L, David. R D, F. J. G, M.S. Dhanoa, Jan. D, James. F, "Assessment of nutritive value of cereal and legume straws based on chemical composition and in vitro digestibility", J. Sci. Food Agric., no.85, pp.15501557, Mar. 7, 2005.

[39] A. K Mosi, and M.H, Butterworth, "The voluntary intake and digestibility of cereal crop residues and legume hay for sheep," Anim Feed Sci Tech., vol. 12, issue 4, pp.241251, July 1985.

[40] B. D. Thomson, Kadambot. HM. S, M.D. Bar, J.M. Wilson, "Grain legume species in low rainfall Mediterranean-type environments: I Phenology and seed yield", Field Crops Res., vol.54, issue 2-3, pp.173-187, Sep.1997.
Publish your research article in AIJR journals-

$\checkmark \quad$ Online Submission and Tracking

$\checkmark$ Peer-Reviewed

$\checkmark \quad$ Rapid decision

$\checkmark \quad$ Immediate Publication after acceptance

$\checkmark \quad$ Articles freely available online

$\checkmark \quad$ Retain full copyright of your article.

Submit your article at journals.aijr.in

Publish your books with AIJR publisher-

$\checkmark \quad$ Publish with ISBN and DOI.

$\checkmark$ Publish Thesis/Dissertation as Monograph.

$\checkmark \quad$ Publish Book Monograph.

$\checkmark \quad$ Publish Edited Volume/ Book.

$\checkmark \quad$ Publish Conference Proceedings

$\checkmark \quad$ Retain full copyright of your books.

Submit your manuscript at books.aijr.org 